\title{
CORRIGENDUM
}

\section{Haploidentical transplantation with post-infusion cyclophosphamide in advanced Hodgkin lymphoma}

L Castagna, S Bramanti, R Devillier, B Sarina, R Crocchiolo, S Furst, J El-Cheikh, A Granata, C Faucher, S Harbi, L Morabito, J Mariotti, S Puvinathan, PJ Weiller, C Chabannon, D Mokart, C Carlo-Stella, R Bouabdallah, A Santoro and D Blaise

Bone Marrow Transplantation (2017) 52, 797; doi:10.1038/bmt.2017.26

Correction to: Bone Marrow Transplantation (2017) 52, 683-688; doi:10.1038/bmt.2016.348; published online 16 January 2017

Since the online publication of this article, it has been noted that the author name JE Cheikh was incorrect and should be replaced with J El-Cheikh.
The authors would like to apologise for this error.

This error has now been rectified, and the corrected article appears in this issue. The $\mathrm{html}$ and online pdf versions have also been rectified, and now carry the corrected paper. 